\title{
Antibacterial effect of water-soluble chitosan on representative dental pathogens Streptococcus mutans and Lactobacilli brevis
}

\author{
Chih-YU CHEN ${ }^{1}$, Ying-CHIEN CHUNG ${ }^{2}$
}

1- PhD, Professor, Department of Tourism and Leisure, Hsing Wu University, Taipei, Taiwan.

2- PhD, Professor, Department of Biological Science and Technology, China University of Science and Technology, Taipei, Taiwan.

Corresponding address: Professor Ying-Chien Chung, No.245, Sec. 3, Academia Rd., Nangang Dist., Taipei City 115, Taiwan - Phone: +886-2-89116337Fax: +886-2-89116338- ycchung@cc.cust.edu.tw

Received: February 28, 2012 - Modification: August 22, 2012 - Accepted: September 14, 2012

\section{ABSTRACT}

\begin{abstract}
$\mathrm{D}$ ental caries is still a major oral health problem in most industrialized countries. The development of dental caries primarily involves Lactobacilli spp. and Streptococcus mutans. Although antibacterial ingredients are used against oral bacteria to reduce dental caries, some reports that show partial antibacterial ingredients could result in side effects. Objectives: The main objective is to test the antibacterial effect of water-soluble chitosan while the evaluation of the mouthwash appears as a secondary aim. Material and Methods: The chitosan was obtained from the Application Chemistry Company (Taiwan). The authors investigated the antibacterial effects of water-soluble chitosan against oral bacteria at different temperatures $\left(25-37^{\circ} \mathrm{C}\right)$ and $\mathrm{pH}$ values $(\mathrm{pH} 5-8)$, and evaluated the antibacterial activities of a self-made water-soluble chitosan-containing mouthwash by in vitro and in vivo experiments, and analyzed the acute toxicity of the mouthwashes. The acute toxicity was analyzed with the pollen tube growth (PTG) test. The growth inhibition values against the logarithmic scale of the test concentrations produced a concentrationresponse curve. The IC50 value was calculated by interpolation from the data. Results: The effect of the $\mathrm{pH}$ variation (5-8) on the antibacterial activity of water-soluble chitosan against tested oral bacteria was not significant. The maximal antibacterial activity of water-soluble chitosan occurred at $37^{\circ} \mathrm{C}$. The minimum bactericidal concentration (MBC) of water-soluble chitosan on Streptococcus mutans and Lactobacilli brevis were $400 \mu \mathrm{g} / \mathrm{mL}$ and $500 \mu \mathrm{g} / \mathrm{mL}$, respectively. Only $5 \mathrm{~s}$ of contact between water-soluble chitosan and oral bacteria attained at least $99.60 \%$ antibacterial activity at a concentration of $500 \mu \mathrm{g} / \mathrm{mL}$. The water-soluble chitosan-containing mouthwash significantly demonstrated antibacterial activity that was similar to that of commercial mouthwashes $(>99.91 \%)$ in both in vitro and in vivo experiments. In addition, the alcohol-free mouthwash exhibited no cytotoxicity and no oral stinging. To the best of our knowledge, this was the first study to combine in vitro and in vivo investigations to analyze the antibacterial properties of water-soluble chitosan-containing mouthwash. Conclusions: This study illustrated that water-soluble chitosan may be a viable alternative to commercial mouthwashes in the future.
\end{abstract}

Key words: Bactericides. Chitosan. Ethanol. Mouthwashes.

\section{INTRODUCTION}

The teeth are covered by bacteria, which constitute dental biofilm, and lactic acid production by these bacteria has long been considered the main pathogenic mechanism for producing caries lesions. Microbiological cultures from the dental biofilm suggested that the acidogenic Lactobacilli spp. and Streptococcus mutans are the pathogens of dental caries because they occur in high numbers in both superficial and deep caries ${ }^{5,13,18,26}$. At present, antibacterial mouthwashes typically contain chlorhexidine and cetylpyridinium chloride, which are used against $S$. mutans and Lactobacilli spp. to reduce dental caries ${ }^{4,29}$. However, chlorhexidine 
has been prohibited in Japan because of possible anaphylaxis ${ }^{14}$, and cetylpyridinium chloride has been alleged to possibly cause teeth staining and taste alteration ${ }^{24}$. Ethanol, another ingredient often used in mouthwashes, is also used as a solvent, preservative, and antiseptic. Studies have shown that high concentrations of ethanol in mouthwash (>20\%) may be associated with detrimental oral effects, such as epithelial detachment, keratosis, mucosal ulceration, gingivitis, petechiae, and pain $^{20}$. Furthermore, the use of antimicrobials (especially for chlorhexidine and cetylpyridinium chloride) may even result in vomiting ${ }^{30}$. Because of this background, the development of a natural, harmless, and ethanol-free antimicrobial agent to reduce cariogenic bacteria is desirable.

Chitosan is a polysaccharide prepared by the de- $N$-acetylation of chitin. Both chitosan and chitin are widely present in crustaceans, insects, fungi, algae, and yeast ${ }^{6}$. Chitosan possesses potent and broad antibacterial qualities and low toxicity for mammalian cells ${ }^{19}$. The natural antibacterial and antifungal characteristics of chitosan and its derivatives have resulted in their use in commercial disinfectants $8,15,22$. Furthermore, studies on the antibacterial activity of chitosan and chitosan oligomers have revealed that chitosan is more effective in inhibiting the growth of bacteria than are chitosan oligomers ${ }^{21}$. In general, chitosan displays greater antifungal activity than chitin, but chitosan is less effective against fungi that possess a chitin component in their cell walls ${ }^{2}$. It is possible that the antibacterial activity of chitosan arises from a combination of both bacteria cell binding and DNA binding mechanisms ${ }^{6}$. However, the application of chitosan in toothpaste or mouthwash is limited because of its insolubility in water; chitosan is soluble only in acid conditions. Previous research had shown that water-soluble chitosan (produced through Maillard reaction or saccharide modification) displayed antibacterial activity against Escherichia coli and Staphylococcus spp. ${ }^{7,33}$. Fujiwara, et al.11 (2004) were the first to report that water-soluble chitosan shows an inhibitory effect on caries-related S. mutans.

This study examined the effects of watersoluble chitosan on oral bacteria, especially $S$. mutans and $L$. brevis. The antibacterial activity was evaluated by various parameters, such as the $\mathrm{pH}$ level and temperature. The possible cytotoxicity of a water-soluble chitosan-containing mouthwash and commercial mouthwashes were also analyzed. Furthermore, we compared the antibacterial activity of commercial mouthwashes and a water-soluble chitosan-containing mouthwash both in vitro and in vivo.

\section{MATERIAL AND METHODS}

\section{1) Preparation of water-soluble chitosan}

The $\alpha$-type chitosan (100 mesh) from shrimp shells, with a deacetylation degree of $90 \%$, was obtained from the Application Chemistry Company (Taiwan). The chitosan was dissolved in $0.2 \mathrm{M}$ acetic acid solution ( $\mathrm{pH} 3.3$ ) for a final concentration of $1 \%$ $(\mathrm{w} / \mathrm{v})$, then mixed with $1 \%$ glucosamine and gently stirred until dissolved. The mixtures were reacted at $65^{\circ} \mathrm{C}$ in an orbital shake incubator for 2 days, at which time samples were drawn and centrifuged (6,000 xg, $15 \mathrm{~min})$. The supernatant was dialyzed against distilled water with a dialysis membrane (molecular weight cut-off 12,000-14,000) for $96 \mathrm{~h}$ and then freeze-dried ${ }^{6}$. The average deacetylation degree of the water-soluble chitosan (chitosanglucosamine derivative) was approximately $80 \%$.

\section{2) Bacterial strains and growth condition}

Twenty healthy adult volunteers (10 men and 10 women) ranging in age from 20 to 25 years were recruited. All volunteers were non-smokers and had no current caries activity. None of the volunteers were using antibiotics or other medications. All volunteers rinsed their oral cavities with $10 \mathrm{ml}$ aseptic water for $20 \mathrm{~s}$ before providing saliva samples. The saliva samples were homogenized by ultra-sonication under water at $5^{\circ} \mathrm{C}$ for $10 \mathrm{~s}$. Serial 10-fold dilutions of the suspensions were prepared. The appropriate dilutions were plated in triplicate on sterile Petri plates containing $20 \mathrm{ml}$ Tryptic Soy Agar (TSA). The plates were incubated at $37^{\circ} \mathrm{C}$ for $18 \mathrm{~h}$. The colony numbers were enumerated if required. Colonies of different types in appearance were selected and isolated. The isolates were stored as glycerol stock at $-20^{\circ} \mathrm{C}$. To identify the isolated strains from the saliva samples, the cells of the dominant isolates were lysed, and DNA was extracted. The 16S rRNA gene sequences of the dominant isolates were compared using BLASTN (Basic Local Alignment Search Tool) programs to search for nucleotide sequences in the NCBI website.

The representative dental pathogens Streptococcus mutans (BCRC 10793) and Lactobacilli brevis (BCRC 10361) were purchased from Bioresource Collection and Research Center (Hsinchu County, Taiwan). S. mutans and L. brevis were cultured in Tryptic Soy Broth (DIFCO 0369) and MRS Broth (DIFCO 0881) under anaerobic conditions, respectively. To prepare the bacterial cultures, the isolated strains were removed from the plates, then inoculated on $100 \mathrm{~mL}$ TSB and incubated at $37^{\circ} \mathrm{C}$ in an orbital incubator at 150 $\mathrm{rpm}$. At an exponential growth phase (10 $10^{7} \mathrm{CFU} /$ $\mathrm{mL} ; \mathrm{OD}_{600}$ of 0.4 ), bacterial cells were collected by centrifugation at $6,000 \times \mathrm{g}$ for $10 \mathrm{~min}$ at $4^{\circ} \mathrm{C}$, and 
the bacterial pellets were washed three times with deionized water. Finally, the bacterial pellets were re-suspended in deionized water. Cell suspensions were diluted with sterile deionized water to $10^{7} \mathrm{CFU} /$ $\mathrm{mL}$ to conduct antibacterial experiments.

\section{3) Effect of various environmental conditions on antibacterial activity of water-soluble chitosan against oral bacteria}

The experiment was conducted transferring $1 \mathrm{ml}$ bacterial cells into the aseptic test tube containing $9 \mathrm{ml}$ of water-soluble chitosan solution. The final concentration of water-soluble chitosan was 100 $\mu \mathrm{g} / \mathrm{mL}$. In the antibacterial experiment, the final cell numbers were $10^{7} \mathrm{CFU} / \mathrm{mL}$, unless stated otherwise. Subsequently, different environmental conditions were established for the $\mathrm{pH}$ level (5-8) and temperature $\left(25-37^{\circ} \mathrm{C}\right)$, and the test tubes in these conditions were reacted separately for 12 $\mathrm{h}$. The different $\mathrm{pH}$ conditions were made by the appropriate buffer solution. After a $12 \mathrm{~h}$ contact period, the solutions were properly diluted and plated on TSB agar or MRS agar, and then incubated at $37^{\circ} \mathrm{C}$ for $18 \mathrm{~h}$. After incubation, the colonies were counted to analyze the bactericidal activity. The minimum bactericidal concentrations (MBC) of isolated oral bacteria S. mutans and L. brevis were determined separately. The MBC value was defined as the lowest concentration of antibacterial agent required to kill the germ. To evaluate the MBC, we inoculated $1 \mathrm{ml}$ bacterial cells into an aseptic test tube containing $1 \mathrm{ml}$ water-soluble chitosan solution at different concentrations $(100-1,000 \mu \mathrm{g} /$ $\mathrm{mL})$, and the test solutions were incubated at $37^{\circ} \mathrm{C}$ for $18 \mathrm{hrs}$. After incubation, $0.1 \mathrm{ml}$ clear solutions (judged by the naked eye) were plated to TSB agar or MRS agar, and then incubated at $37^{\circ} \mathrm{C}$ for $18 \mathrm{~h}$ to evaluate the MBC.

To evaluate the optimal contact time for antibacterial activity, $1 \mathrm{ml}$ bacterial cells were transferred into the aseptic test tube containing $9 \mathrm{ml}$ of water-soluble chitosan solution (final concentration: $500 \mu \mathrm{g} / \mathrm{mL}$ ) under the conditions of $\mathrm{pH} 7,37^{\circ} \mathrm{C}$, and variable contact times (5, 10, 20, 30, 45, and 60 s, separately). The reacted solution was then plated to TSB agar or MRS agar and incubated at $37^{\circ} \mathrm{C}$ for $18 \mathrm{~h}$ to evaluate the antibacterial activity of water-soluble chitosan. All the experiments were performed in triplicate.

4) The in vitro and in vivo study of antibacterial activity by mouthwashes

For the in vitro experiment, we collected five different types of commercial mouthwashes ( $A, B$, $C, D$, and E), one self-made water-soluble chitosancontaining mouthwash $(F)$, pure water as the control (G), a menthol solution of $0.07 \%(\mathrm{H})$, and a menthol solution of $0.007 \%$ (I). The ingredients of our self- made mouthwash was comprised of $500 \mu \mathrm{g} / \mathrm{mL}$ water-soluble chitosan and $0.007 \%$ menthol (for flavor), and the mouthwash's pH level was 7.2. Two of the tested commercial mouthwashes contained ethanol; the other three types of commercial mouthwashes were ethanol-free. We transferred $1 \mathrm{ml}$ of six types of mixed bacteria solution into the aseptic test tube containing $9 \mathrm{ml}$ mouthwash solution and reacted the mixture at $37^{\circ} \mathrm{C}$. After a reaction time of $20 \mathrm{~s}$, the solution was plated on TSB agar or MRS agar, incubated at $37^{\circ} \mathrm{C}$ for $18 \mathrm{~h}$, and then the numbers of microbial colonies were counted.

The purpose of the in vivo study was to determine and compare the antibacterial activities of the types of commercial mouthwashes, self-made water-soluble chitosan containing mouthwash, and water control. The antibacterial activities of these products were determined against bacteria in the saliva samples. The same 20 volunteers who participated in the previous part of the study again acted as our study participants for the in vivo trial. At each experimental session for a participant, pretest saliva samples were taken by rinsing with $10 \mathrm{ml}$ deionized water as the control groups one day before. The oral cavities of the volunteers were rinsed with one type of mouthwash $(10 \mathrm{ml})$ or the water control for $20 \mathrm{~s}$, before collecting post-test saliva samples. The washout period of different mouthwashes was at least $48 \mathrm{~h}$. Following an $18 \mathrm{~h}$ incubation period, the numbers of bacterial colonies on specific plates (TSB agar or MRS agar) were counted, and compared with the results of the pretest saliva samples. The antibacterial activity of water-soluble chitosan or mouthwash was defined as:

Antibacterial activity $(\%)=\frac{(\text { initial } \text { cell number }- \text { cell number after treatment) }}{\text { initial cell number }} \times 100 \%$

5) Assays for acute toxicity of mouthwashes The acute toxicity of each mouthwash (A-I) was analyzed with the pollen tube growth (PTG) test. The PTG test is easy to administer and is a sensitive system for analyzing the toxicity at the cellular level because the growth of pollen tubes is inhibited in the presence of toxic substances. The PTG test used in this study complied with the report by Kristen and Friedrich ${ }^{17}$ (2006). To test each mouthwash, $0.1 \mathrm{ml}$ of mouthwash was added to the Nicotiana sylvestris pollen suspensions. The suspensions were incubated for $18 \mathrm{~h}$ at $25^{\circ} \mathrm{C}$ to permit pollen germination and tube growth. Each experiment was repeated independently at least three times, and each concentration group was assayed in triplicate. Thereafter, IC $_{50}$ values were determined for each mouthwash. The statistical analyses were performed using SPSS Software ver. 16.0. The measurements were expressed as the mean and standard deviation (SD) for each group. 


\section{RESULTS}

Four oral strains of bacteria (Staphylococcus saprophyticus, Staphylococcus aureus, Klebsiella pneumoniae, Enterobacter gergoviae) were isolated from the saliva samples of 20 healthy adult volunteers. The representative dental pathogens Streptococcus mutans and Lactobacillus brevis were purchased from BCRC (HsinChu, Taiwan). The optimal growth $\mathrm{pH}$ level and temperature of the six oral strains included in this experiment are shown in Table 1 . The findings indicated that the optimal growth $\mathrm{pH}$ level of $L$. brevis and S. saprophyticus were $5.8 \pm 0.3$ and $5.3 \pm 0.7$, respectively. Furthermore, the optimal growth temperature of $L$. brevis and E. gergoviae was $30^{\circ} \mathrm{C}$.

Table 2 indicates that the maximal antibacterial activity of water-soluble chitosan is $67.0 \pm 2.3 \%$ at $\mathrm{pH} 5$ for $K$. pneumonia; $86.1 \pm 1.4 \%$ at $\mathrm{pH} 8$ for E. gergoviae; $95.3 \pm 1.0 \%$ at $\mathrm{pH} 5$ for S. mutans; $72.4 \pm 1.2 \%$ at $\mathrm{pH} 8$ for L. brevis; $57.2 \pm 1.9 \%$ at 8 for S. saprophyticus; and $80.1 \pm 2.2 \%$ at $\mathrm{pH} 5$ for S. aureus. The effect of the $\mathrm{pH}$ variation (5-7) on the antibacterial activity of water-soluble chitosan against these oral bacteria was not statistically significant. Based on the results and considering the application, the $\mathrm{pH}$ value for antibacterial activity of water-soluble chitosan against tested oral bacteria was set $\mathrm{pH} 7$.

Table 3 indicates that maximal antibacterial activity occurred at $37^{\circ} \mathrm{C}$, and antibacterial activity is $68.0 \pm 3.2 \%$ for $K$. pneumoniae, $81.2 \pm 5.0 \%$ for $E$. gergoviae, $96.2 \pm 1.3 \%$ for $S$. mutans, $67.0 \pm 2.8 \%$ for $L$. brevis, $50.1 \pm 3.0 \%$ for S. saprophyticus, and $80.6 \pm 3.3 \%$ for $S$. aureus. Based on the reported results, we set the temperature for antibacterial activity of water-soluble chitosan against tested

Table 1- The optimal temperature and $\mathrm{pH}$ of six in vitro growth oral bacteria strains

\begin{tabular}{cccccc}
\hline $\begin{array}{c}\text { Bacteria species } \\
\text { identification }\end{array}$ & $\begin{array}{c}\text { Accession } \\
\text { number }\end{array}$ & Similarity & Classification & Temperature $\left({ }^{\circ} \mathbf{C}\right)$ & pH \\
\hline $\begin{array}{c}\text { Lactobacillus } \\
\text { brevis }\end{array}$ & - & - & Firmicutes & $30 \pm 0.5$ & $5.8 \pm 0.3$ \\
$\begin{array}{c}\text { Streptococcus } \\
\text { mutans }\end{array}$ & - & - & Firmicutes & $37 \pm 0.6$ & $7.0 \pm 0.6$ \\
$\begin{array}{c}\text { Staphylococcus } \\
\text { saprophyticus }\end{array}$ & EU073967.1 & $99.2 \%$ & Firmicutes & $37 \pm 1.0$ & $5.3 \pm 0.7$ \\
$\begin{array}{c}\text { Staphylococcus } \\
\text { aureus }\end{array}$ & FJ899095.1 & $99.5 \%$ & Firmicutes & $37 \pm 0.5$ & $7.4 \pm 0.6$ \\
$\begin{array}{c}\text { Klebsiella } \\
\text { pneumoniae }\end{array}$ & AP006725.1 & $99.1 \%$ & Proteobacteria & $37 \pm 0.8$ & $7.0 \pm 0.5$ \\
$\begin{array}{c}\text { Enterobacter } \\
\text { gergoviae }\end{array}$ & NR_024641.1 & $99.6 \%$ & Proteobacteria & $30 \pm 1.1$ & $7.0 \pm 0.6$ \\
\hline
\end{tabular}

Table 2- Effects of $\mathrm{pH}$ on antibacterial activity against oral bacteria by addition of water-soluble chitosan (temperature: $37^{\circ} \mathrm{C}$, bacteria cell: $10^{7} \mathrm{CFU} / \mathrm{mL}$ )

\begin{tabular}{ccccc}
\hline & \multicolumn{3}{c}{ Antibacterial activity (\%) } & pH=8 \\
\hline $\begin{array}{c}\text { Klebsiella } \\
\text { pneumoniae }\end{array}$ & $67.0 \pm 2.3$ & $\mathrm{pH}=\mathbf{6}$ & $\mathbf{p H = 7}$ & $45.0 \pm 0.5$ \\
$\begin{array}{c}\text { Enterobacter } \\
\text { gergoviae }\end{array}$ & $82.3 \pm 3.5$ & $63.2 \pm 1.6$ & $60.2 \pm 0.8$ & $86.1 \pm 1.4$ \\
$\begin{array}{c}\text { Streptococcus } \\
\text { mutans }\end{array}$ & $95.3 \pm 1.0$ & $80.1 \pm 2.7$ & $82.0 \pm 1.9$ & $78.7 \pm 0.8$ \\
$\begin{array}{c}\text { Lactobacillus } \\
\text { brevis }\end{array}$ & $67.2 \pm 3.4$ & $93.0 \pm 1.2$ & $91.5 \pm 0.7$ & $72.4 \pm 1.2$ \\
$\begin{array}{c}\text { Staphylococcus } \\
\text { saprophyticus }\end{array}$ & $52.1 \pm 2.1$ & $65.0 \pm 1.6$ & $68.3 \pm 1.8$ & $57.2 \pm 1.9$ \\
\hline $\begin{array}{c}\text { Staphylococcus } \\
\text { aureus }\end{array}$ & $80.1 \pm 2.2$ & $52.5 \pm 0.6$ & $53.1 \pm 1.2$ & $64.0 \pm 1.7$ \\
\hline
\end{tabular}


Table 3- Effects of temperature on antibacterial activity against oral bacteria by addition of water-soluble chitosan ( $\mathrm{pH}$ : 7 , bacteria cell: $10^{7} \mathrm{CFU} / \mathrm{mL}$ )

\begin{tabular}{cccc}
\hline & \multicolumn{3}{c}{ Antibacterial activity (\%) } \\
\hline Klebsiella pneumoniae & $\mathbf{2 5}{ }^{\circ} \mathbf{C}$ & $\mathbf{3 0}{ }^{\circ} \mathbf{C}$ & $\mathbf{3 7}{ }^{\circ} \mathbf{C}$ \\
\hline Enterobacter gergoviae & $51.0 \pm 2.2$ & $60.3 \pm 1.0$ & $68.0 \pm 3.2$ \\
Streptococcus mutans & $55.1 \pm 1.5$ & $72.2 \pm 3.5$ & $81.2 \pm 5.0$ \\
Lactobacillus brevis & $64.2 \pm 2.0$ & $72.0 \pm 2.5$ & $96.2 \pm 1.3$ \\
Staphylococcus saprophyticus & $33.2 \pm 1.5$ & $55.2 \pm 3.4$ & $67.0 \pm 2.8$ \\
Staphylococcus aureus & $38.5 \pm 2.2$ & $45.6 \pm 1.5$ & $50.1 \pm 3.0$ \\
\hline
\end{tabular}

Table 4- Effects of contact time on antibacterial activity against oral bacteria by the addition of water-soluble chitosan ( $\mathrm{pH}$ : 7, bacteria cell: $10^{7} \mathrm{CFU} / \mathrm{mL}$ )

\begin{tabular}{cccccc}
\hline & \multicolumn{5}{c}{ Antibacterial activity (\%) } \\
\hline $\begin{array}{c}\text { Klebsiella } \\
\text { pneumoniae } \\
\begin{array}{c}\text { Enterobacter } \\
\text { gergoviae }\end{array}\end{array}$ & $99.75 \pm 0.02$ & $99.99 \pm 0.01$ & $99.99 \pm 0.00$ & $99.99 \pm 0.00$ & $99.99 \pm 0.00$ \\
$\begin{array}{c}\text { Streptococcus } \\
\text { mutans }\end{array}$ & $99.68 \pm 0.02$ & $99.99 \pm 0.01$ & $99.99 \pm 0.00$ & $99.99 \pm 0.00$ & $99.99 \pm 0.00$ \\
$\begin{array}{c}\text { Lactobacillus } \\
\text { brevis }\end{array}$ & $99.78 \pm 0.01$ & $99.85 \pm 0.01$ & $99.99 \pm 0.00$ & $99.99 \pm 0.00$ & $99.99 \pm 0.00$ \\
$\begin{array}{c}\text { Staphylococcus } \\
\text { saprophyticus }\end{array}$ & $99.65 \pm 0.03$ & $99.99 \pm 0.01$ & $99.99 \pm 0.01$ & $99.99 \pm 0.00$ & $99.99 \pm 0.00$ \\
$\begin{array}{c}\text { Staphylococcus } \\
\text { aureus }\end{array}$ & $99.60 \pm 0.03$ & $99.81 \pm 0.02$ & $99.99 \pm 0.01$ & $99.99 \pm 0.00$ & $99.99 \pm 0.00$ \\
\hline
\end{tabular}

Table 5- Comparison of pollen tube growth (PTG) test data of nine kinds of mouthwashes. A-E were five kinds of commercial mouthwashes; $F$ was self-made watersoluble chitosan containing mouthwash $(\mathrm{pH}=7,500 \mu \mathrm{g} /$ $\mathrm{mL}$ ); $\mathrm{G}$ was pure water (control); $\mathrm{H}$ was $0.07 \%$ menthol solution; I was $0.007 \%$ menthol solution

\begin{tabular}{cc}
\hline Different mouthwashes & $\mathrm{IC}_{50}$ value $(\mu \mathrm{g} / \mathrm{mL})$ \\
\hline A & $3,556 \pm 412$ \\
B & $1,784 \pm 105$ \\
C & $2,263 \pm 133$ \\
D & $4,643 \pm 308$ \\
E & $5,690 \pm 278$ \\
F & $>100,000$ \\
G & $>100,000$ \\
H & $7,140 \pm 407$ \\
I & $>100,000$ \\
\hline
\end{tabular}

oral bacteria at $37^{\circ} \mathrm{C}$.

The experimental results indicated that the MBC of K. pneumoniae, L. brevis, and S. saprophyticus were $500 \mu \mathrm{g} / \mathrm{mL}$, and that the MBC of $S$. aureus, S. mutans, and E. gergoviae were $400 \mu \mathrm{g} / \mathrm{mL}$. The strains of $K$. pneumoniae, L. brevis, and $S$. saprophyticus were difficult to kill compared with S. aureus, S. mutans, and E. gergoviae.

Only $5 \mathrm{~s}$ of contact between water-soluble chitosan and the tested solution containing oral bacteria could attain at least $99.60 \%$ antibacterial activity. Moreover, 20 s of contact time was sufficient to achieve $99.99 \%$ antibacterial activity against all six bacteria strains, with insignificant differences between the antibacterial effect against the various strains $(p>0.05)$ (Table 4$)$. Thus, the ideal contact time for water-soluble chitosan appears to be $20 \mathrm{~s}$.

The PTG test results of nine types of mouthwashes, including the controls, are summarized in Table 5. The $\mathrm{IC}_{50}$ values ranged from 1,784 to $>10,000 \mu \mathrm{g} /$ $\mathrm{mL}$. The $\mathrm{IC}_{50}$ of water-soluble chitosan containing mouthwash $(F)$, water solution $(G)$, and $0.007 \%$ menthol solution were all $>100,000 \mu \mathrm{g} / \mathrm{mL}$. The $\mathrm{IC}_{50}$ 
Table 6- The comparison of different mouthwashes. A-E were five commercial mouthwashes; $F$ was self-made watersoluble chitosan containing mouthwash $(\mathrm{pH}=7,500 \mu \mathrm{g} / \mathrm{mL}$ ); $\mathrm{G}$ was pure water (control); $\mathrm{H}$ and I were $0.07 \%$ menthol solution and $0.007 \%$ menthol solution, respectively

\begin{tabular}{crrc}
\hline mouthwashes & Major ingredients & pH & drawbacks \\
\hline A & chlorhexidine, xylitol, sodium fluoride, menthol $(0.07 \%)$, & 6.4 & alcohol containing \\
glycerin, alcohol & & alcohol containing \\
B & chlorhexidine, menthol $(0.07 \%)$, alcohol & 5.0 & oral stinging \\
C & thyme oil, eucalyptus oil, wintergreen oil, peppermint oil & 4.3 & oral stinging \\
D & cetylpyridinium chloride, sodium fluoride & 6.4 & too long contact time (1 min) \\
E & sodium fluoride, glycerin, sodium benzoate & 6.9 & little astringent taste \\
F & water-soluble chitosan, menthol $(0.007 \%)$ & 5.0 & low antibacterial activity \\
G & pure water (pH adjusted to 5) & 5.0 & hypersensitivity reactions \\
H & menthol solution $(0.07 \%)$ & 6.0 & medium antibacterial activity \\
\hline I & menthol solution $(0.007 \%)$ & &
\end{tabular}

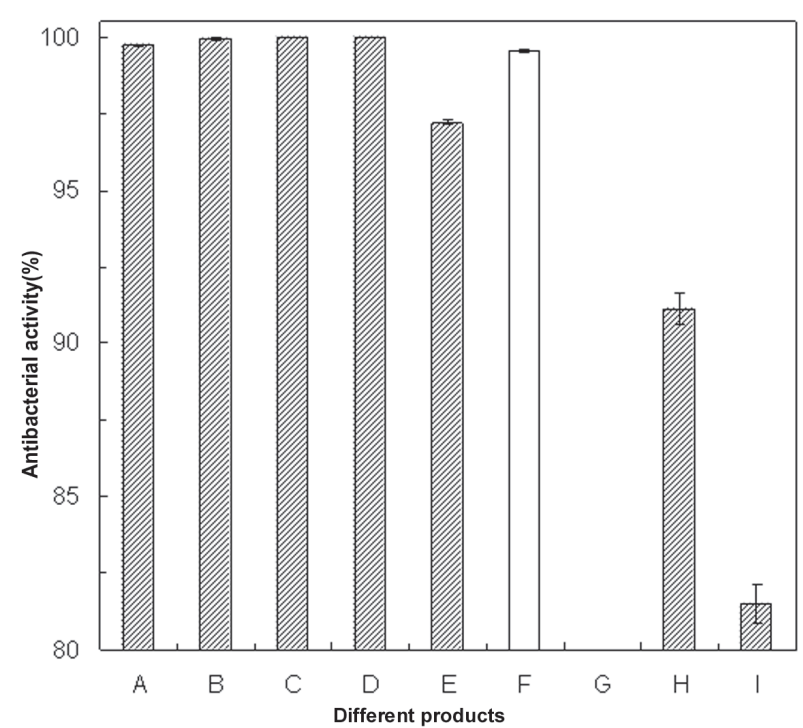

Figure 1- Effects of mouthwashes in vitro on antibacterial activities against mixed bacteria solution at $20 \mathrm{~s}$ contact time. A-E were five commercial mouthwashes; $F$ was self-made water-soluble chitosan containing mouthwash $(\mathrm{pH}=7,500 \mu \mathrm{g} / \mathrm{mL}) ; \mathrm{G}$ was pure water; $\mathrm{H}$ and I were $0.07 \%$ menthol solution and $0.007 \%$ menthol solution, respectively

of five types of commercial mouthwashes ranged from $1,784 \pm 105 \mu \mathrm{g} / \mathrm{mL}$ to $5,690 \pm 278 \mu \mathrm{g} / \mathrm{mL}$. The $\mathrm{IC}_{50}$ of $0.07 \%$ menthol solution (the concentration that was present in the commercial mouthwash) was $7,140 \pm 407 \mu \mathrm{g} / \mathrm{mL}$.

In our in vitro study, the self-made mouthwash containing water-soluble chitosan had similar $(p>0.05)$ or higher antibacterial activity than the commercial mouthwash (Figure 1). Although the reduction in bacteria counts in the tested volunteers after they had rinsed with $0.07 \%$ menthol solution was lower than that induced by the commercial mouthwash, the $0.07 \%$ menthol solution alone

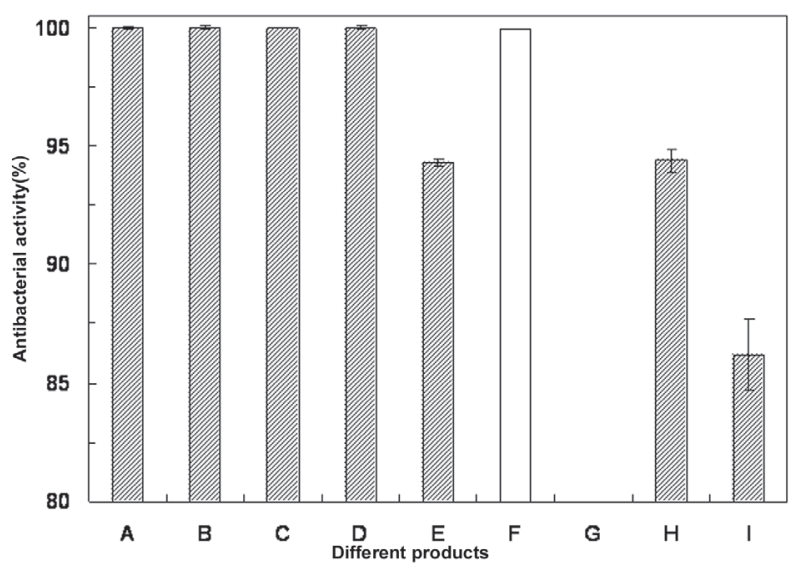

Figure 2- Effects of mouthwashes on antibacterial activity against oral bacteria of twenty volunteer adult people at $20 \mathrm{~s}$ contact time. A-E were five commercial mouthwashes; F was self-made water-soluble chitosan containing mouthwash $(\mathrm{pH}=7,500 \mu \mathrm{g} / \mathrm{mL}) ; \mathrm{G}$ was pure water; $\mathrm{H}$ and I were $0.07 \%$ menthol solution and $0.007 \%$ menthol solution, respectively

was still effective against mixed bacteria (91.1\% antibacterial activity).

The in vivo results showed that the reduction of bacteria counts after rinsing with the watersoluble chitosan-containing mouthwash was similar $(p>0.05)$ to the bacterial reduction observed for the commercial mouthwash (Figure 2). Table 6 summarizes the adverse effects of major ingredients of commercial mouthwashes, as reported in previous studies ${ }^{12}$, and also as reported by the individual volunteers in our study. Our results indicated that alcohol-containing types of mouthwash $A$ and $B$ displayed high antibacterial activity (Figures 1 and 2), but they would harm oral tissues. Types of mouthwash $\mathrm{C}$ and $\mathrm{D}$ also exhibited high antibacterial activity (Figures 1 and 2), but they resulted in oral stinging. Although mouthwash 
E was alcohol-free, it exhibited weak antibacterial activity in 20 s contact time.

\section{DISCUSSION}

Kong, et al. ${ }^{16}$ (2010) reported that acid-soluble chitosan shows a stronger inhibitory effect at a lower pH level, with inhibitory activity weakening with an increasing $\mathrm{pH}$ level. The failure of acidsoluble chitosan to remain bactericidal at $\mathrm{pH} 7$ may be due to the presence of a large majority of uncharged amino groups, as well as poor solubility of chitosan in a $\mathrm{pH}$-neutral environment ${ }^{1}$. In our study, water-soluble chitosan showed significantly wider antibacterial activity ( $\mathrm{pH}$ from 5 to 8 ) compared with the results previously reported from studies using acid-soluble chitosan ${ }^{16}$.

Temperature substantially affects the antibacterial activity of water-soluble chitosan. This finding may have been due to the physiological characteristics of the tested bacteria themselves or to reaction kinetics between the tested bacteria and antibacterial chitosan. Tsai and Su ${ }^{28}$ (1999) reported that the susceptibility of $E$. coli to chitosan increased in conjunction with the temperature, indicating that low temperatures would be capable of changing the cell surface structure and decreasing the number of surface binding sites for chitosan. Our results indicated the optimal temperature for antibacterial activity of water-soluble chitosan against tested oral bacteria was $37^{\circ} \mathrm{C}$.

The minimum bactericidal concentration (MBC) is the lowest concentration of antibiotic required to kill a particular bacterium. The MBC of chitosan often depends on the bacterial species and the molecular weight of the chitosan ${ }^{31}$. Bae, et al. ${ }^{3}$ (2006) reported that the MBC of water-soluble chitosan (70\% degree of deacetylation) for S. mutans was $1,250 \mu \mathrm{g} / \mathrm{mL}$. Qin, et al. ${ }^{23}$ (2006) reported that water-soluble chitosan (50\% degree of deacetylation) exhibited no significant antimicrobial activity. However, Xie, et al. ${ }^{32}$ (2002) reported that a water-soluble chitosan derivative (hydroxypropyl chitosan) showed excellent antibacterial activity against $E$. coli and $S$. aureus. The variation in antibacterial activity of water-soluble chitosan may be due to differing degrees of affinity between the cell walls of the bacteria and the water-soluble chitosan, or different degrees of deacetylation of the chitosan ${ }^{10}$.

In general, the recommended contact time of commercial mouthwashes ranges from 30 to $60 \mathrm{~s}^{25}$. Tomas, et al. ${ }^{27}$ (2010) reported that the antibacterial activity was improved by extending the contact duration to more than $60 \mathrm{~s}$ to kill certain bacterial strains. In this study, water-soluble chitosan appears to be highly effective and appropriate as an antibacterial ingredient in mouthwash.

A study by Kristen and Friedrich ${ }^{17}$ (2006) found that the $\mathrm{IC}_{50}$ values for 20 types of mouthwashes ranged from 541 to $>49,326 \mu \mathrm{g} / \mathrm{mL}$. Based on these results, we concluded that a commercial mouthwash contains a higher cytotoxicity than a water-soluble chitosan-containing mouthwash.

This concentration of menthol $(0.07 \%)$ corresponded with the amount that was generally present in the commercial mouthwash we tested. The antibacterial ingredients of most types of commercial mouthwashes include menthol, in addition to an antibacterial agent. Our self-made mouthwash contained trace menthol $(0.007 \%)$ for flavor, and was found to contribute to approximately $81.5 \%$ antibacterial activity. Because a $0.07 \%$ menthol solution resulted in cytotoxicity (Table 5), the necessity of adding concentrated menthol to the commercial mouthwash should be discussed.

Our in vivo results confirmed the in vitro results, indicating that a water-soluble chitosan-containing mouthwash was effective in reducing human oral bacteria. Moreover, the in vivo results demonstrated higher efficiency than the in vitro experiments. The differences may have been due to differences in the structures of bacterial communities or bacterial cell concentrations between the in vivo and in vitro experiments. Although the types of commercial mouthwashes ( $A-D$ ) exhibited strong antibacterial activity, commercial mouthwashes are known to have a number of drawbacks, such as enamel staining, burning sensations, and changes in taste perception. Numerous types of commercial mouthwashes also contain alcohol, which has been implicated in oral cancer ${ }^{9}$.

In summary, the analysis of the major ingredients of mouthwashes, in addition to the results of the sensory evaluation, as well as the results of the analysis of antibacterial activity, clearly indicated that water-soluble chitosan is promising as an antibacterial agent for mouthwashes. These findings are significant, despite a little astringent taste in water-soluble chitosan.

\section{ACKNOWLEDGMENTS}

The work was partially supported by a Grant from the National Science Council.

\section{REFERENCES}

1- Aiedeh K, Taha MO. Synthesis of iron-crosslinked chitosan succinate and iron-crosslinked hydroxamated chitosan succinate and their in vitro evaluation as potential matrix materials for oral theophylline sustained-release beads. Eur J Pharm Sci. 2001;13:159-68.

2- Allan CR, Hardwiger LA. The fungicidal effect of chitosan on fungi of varying cell wall composition. Exp Mycol. 1979;3:285-7. 3- Bae K, Jun EJ, Lee SM, Paik DI, Kim JB. Effect of water-soluble reduced chitosan on Streptococcus mutans, plaque regrowth and biofilm vitality. Clin Oral Invest. 2006;10:102-7. 
4- Bagatin CR, Ito IY, Andrucioli MC, Nelson-Filho P, Ferreira JT. Corrosion in Haas expanders with and without use of an antimicrobial agent: an in situ study. J Appl Oral Sci. 2011;19:6627.

5- Byun R, Nadkarni MA, Chhour KL, Martin, FE, Jacques NA, Hunter N. Quantitative analysis of diverse Lactobacillus species present in advanced dental caries. J Clin Microbiol. 2004;42:312836.

6- Chung YC, Chen CY. Antibacterial characteristics and activity of acid-soluble chitosan. Bioresour Technol. 2008;99:2806-14.

7- Chung YC, Kuo CL, Chen CC. Preparation and important functional properties of water-soluble chitosan produced through Maillard reaction. Bioresour Technol. 2005;96:1473-82.

8- Chung YC, Wang HL, Chen YM, Li SL. Effect of abiotic factors on the antibacterial activity of chitosan against waterborne pathogens. Bioresour Technol. 2003;88:179-84.

9- Conway D. Oral health, mouthwashes and cancer - what is the story? Evid Based Dent. 2009;10:6-7.

10- Feng Y, Xia W. Preparation, characterization and antibacterial activity of water-soluble O-fumaryl-chitosan. Carbohyd Polym. 2011;83:1169-73.

11- Fujiwara M, Hayashi $Y$, Ohara N. Inhibitory effect of watersoluble chitosan on growth of Streptococcus mutans. New Microbiol. 2004;27:83-6.

12- Gagari E, Kabani S. Adverse effects of mouthwash use: a review. Oral Surg Oral Med Oral Pathol Oral Radiol Endod. 1995;80:432-9.

13- Hahn CL, Falkler WA Jr, Minah GE. Microbiological studies of carious dentine from human teeth with irreversible pulpitis. Arch Oral Biol. 1991;36:147-53.

14- Hayashi Y, Ohara N, Ganno T, Yamaguchi K, Ishizaki T, Nakamura T, et al. Chewing chitosan-containing gum effectively inhibits the growth of cariogenic bacteria. Arch Oral Biol. 2007;52:290-4.

15- Kim CH, Kim SY, Choi KS. Synthesis and antibacterial activity of water-soluble chitin derivatives. Polym Adv Technol. 1997;8:319-25.

16- Kong M, Chen XG, Xing K, Park HJ. Antimicrobial properties of chitosan and mode of action: a state of the art review. Int $J$ Food Microbiol. 2010;144:51-63.

17- Kristen $U$, Friedrich RE. Toxic screening of mouthwashes in the pollen tube growth test: safety assessment of recommended dilutions. Braz Dent J. 2006;17:58-62.

18- Lima GQ, Oliveira EG, Souza JI, Monteiro Neto V. Comparsion of the efficacy of chemomechanical and mechanical methods of caries removal in the reduction of Streptococcus mutans and Lactobacillus spp in carious dentine of primary teeth. J Appl Oral Sci. 2005;13:399-405.

19- Liu XF, Guan YL, Yang DZ, Li Z, De Yao K. Antibacterial action of chitosan and carboxymethylated chitosan. J Appl Polym Sci. 2001;79:1324-35.
20- McCullough MJ, Farah CS. The role of alcohol in oral carcinogenesis with particular reference to alcohol-containing mouthwashes. Aust Dent J. 2008;53:302-5.

21- No HK, Park NY, Lee SH, Meyers SP. Antibacterial activity of chitosans and chitosan oligomers with different molecular weights. Int J Food Microbiol. 2002;74:65-72.

22- Papineau AM, Hoover DG, Knorr K, Farkas DF. Antimicrobial effect of water-soluble chitosans with high hydrostatic pressure. Food Biotechnol. 1991;5:45-57.

23- Qin CQ, Li HR, Xiao Q, Liu Y, Zhu JC, Du YM. Water-solubility of chitosan and its antimicrobial activity. Carbohydr Polym. 2006;63: 367-74.

24- Quirynen M, Soers C, Desnyder M, Dekeyser C, Pauwels M, van Steenberghe D. A $0.05 \%$ cetyl pyridinium chloride $/ 0.05 \%$ chlorhexidine mouth rinse during maintenance phase after initial periodontal therapy. J Clin Periodontol. 2005;32:390400.

25- Ramage G, Jose A, Coco B, Rajendran R, Rautemaa R, Murray $C$, et al. Commercial mouthwashes are more effective than azole antifungals against Candida albicans biofilms in vitro. Oral Surg Oral Med Oral Pathol Oral Radiol Endod. 2011;111:456-60.

26- Sato TP. A pH curve of human resting saliva sampled with a small paper slip and its medical application. Pathophysiology. 2002;8:283-90.

27- Tomás I, Cousido MC, García-Caballero L, Rubido S, Limeres J, Diz P. Substantivity of a single chlorhexidine mouthwash on salivary flora: influence of intrinsic and extrinsic factors. J Dent. 2010;38:541-6.

28- Tsai GJ, Su WH. Antibacterial activity of shrimp chitosan against Escherichia coli. J Food Prot. 1999;62:239-43.

29- Watanabe E, Tanomaru JM, Nascimento AP, Matoba-Júnior F, Tanomaru-Filho M, Yoko Ito I. Determination of the maximum inhibitory dilution of cetylpyridinium chloride-based mouthwashes against Staphylococcus aureus: an in vitro study. J Appl Oral Sci. 2008; 16:275-9.

30- Wu-Yuan CD, Chen CY, Wu RT. Gallotannins inhibit growth, water-insoluble glucan synthesis and aggregation of mutans streptococci. J Dent Res. 1988;67:51-5.

31- Xia W, Liu P, Zhang J, Chen J. Biological activities of chitosan and chitooligosaccharides. J Food Hydrocoll. 2011;25:170-9.

32- Xie WM, Xu PX, Wang W, Liu Q. Preparation and antibacterial activity of a water-soluble chitosan derivative. Carbohydr Polym. 2002;50:35-40.

33- Yang TC, Chou CC, Li CF. Antibacterial activity of N-alkylated disaccharide chitosan derivatives. Int J Food Microbiol. 2005; $97: 237-45$. 